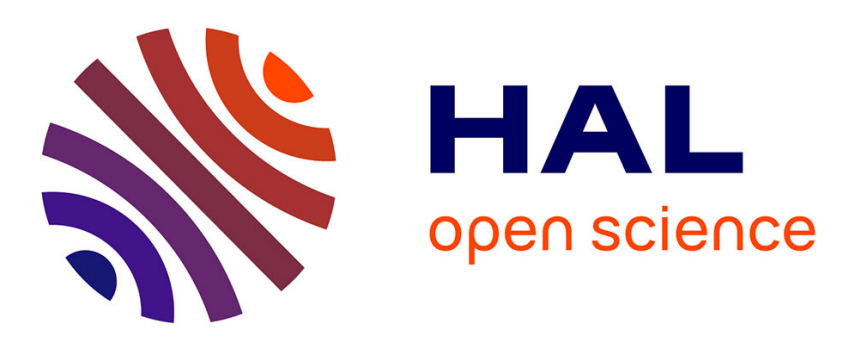

\title{
Encounter as revelation. A Taoist hagiographie theme in medieval China
}

\author{
Franciscus Verellen
}

\section{To cite this version:}

Franciscus Verellen. Encounter as revelation. A Taoist hagiographie theme in medieval China. Bulletin de l'Ecole française d'Extrême-Orient, 1998, 85 (1), pp.363-384. 10.3406/befeo.1998.3837 . halshs02428845

\section{HAL Id: halshs-02428845 \\ https://shs.hal.science/halshs-02428845}

Submitted on 6 Jan 2020

HAL is a multi-disciplinary open access archive for the deposit and dissemination of scientific research documents, whether they are published or not. The documents may come from teaching and research institutions in France or abroad, or from public or private research centers.
L'archive ouverte pluridisciplinaire HAL, est destinée au dépôt et à la diffusion de documents scientifiques de niveau recherche, publiés ou non, émanant des établissements d'enseignement et de recherche français ou étrangers, des laboratoires publics ou privés. 

China

Franciscus Verellen

Citer ce document / Cite this document :

Verellen Franciscus. Encounter as revelation. A Taoist hagiographie theme in medieval China . In: Bulletin de l'Ecole française d'Extrême-Orient. Tome 85, 1998. pp. 363-384;

doi : https://doi.org/10.3406/befeo.1998.3837

https://www.persee.fr/doc/befeo_0336-1519_1998_num_85_1_3837

Fichier pdf généré le 08/02/2019 


\title{
Encounter as revelation A Taoist hagiographic theme in medieval China
}

\author{
Franciscus VERELLEN*
}

\begin{abstract}
Encounters with gods and immortals occupy a prominent place in Taoism. If immortality was the ultimate goal of Taoist practice and its secrets could be divulged by those who had already attained it, then "encounters" provided a setting for initiation and a means to eventual liberation. Since the natural world of mortals was contiguous to supernatural realms inhabited by immortals - hidden among the sacred mountains and rivers - Taoist adepts would scour such promising liminal regions in the hope of encounters. The Taoist encounter quest parallels excursions in search of visions in certain Buddhist pilgrimage traditions. ${ }^{1}$ In time, the intentional and assiduous pursuit of encounters with immortals became a metaphor for the adept's spiritual journey, and the expectation of direct revelatory communion through encounters engendered a devotional literature of its own.
\end{abstract}

\section{The Shenxian ganyu zhuan and Taoist hagiography}

The subject of the present study is the early tenth-century collection Encounters with Immortals, Shenxian ganyu zhuan 神仙感遇傳, by Du Guangting 杜光庭 (850933). In this work, the transmission of sacred and supernatural writings (hagiographa), their revelatory nature and the transformative effect of reading, reciting, and transcribing them are recurrent topics. The typical narrative in Encounters with Immortals is in the form of a biography. The writing of such Lives - tales of sanctity and immortality attained or sometimes narrowly missed - represents the quintessential form of Taoist hagiography. Its aim was practical and devotional, in much the way the early Lives of Christian saints and martyrs served devotional or liturgical purposes. Everyday human failings here received as much attention as their occasional, sensational transcendence. Salvation, when it occurred, was frequently represented as a reward for exceptional merit, devotion, or perseverance; yet almost as often it was the result of happenstance. It is above all this moral ambivalence and humanistic approach to the fulfillment of religious endeavor that seem quite unlike the eschatological perspectives offered by other religions. Taoist encounter literature, thanks to its deliberate examination of the threshold between the human and the divine spheres in

* Membre de l'École française d'Extrême-Orient.

1. See Robert M. Gimello, "Chang Shang-ying on Wu-t'ai shan," in Pilgrims and sacred sites in China, edited by Susan Naquin and Yü Chün-fang, 89-149 (Berkeley: University of California Press, 1992) and Yü Chün-fang, "P'u-t'o shan: Pilgrimage and the creation of the Chinese Potalaka," ibid., 190-246. 
traditional Chinese thinking, may therefore be an instructive case for comparative studies in hagiography.

The acknowledged ancestor of all Taoist hagiographies is the Lives of the Immortals, Liexian zhuan 列仙傳, of the Later Han period (AD 25-220). Ostensibly a collection of biographies 傳, the work provides bare outlines of information about the techniques of physical and spiritual purification through which its subjects attained immortality; it also contains mythical descriptions of the "feathered men 羽人," metallurgists, alchemists, and magicians that populated the Han pantheon of immortals. ${ }^{2}$ Some of these characters were associated with remote and more or less fantastic lands, in the tradition of the Classic of Mountains and Seas, Shanhai jing 山海經, a comprehensive geography that began to take shape in the fourth century BC. A roughly contemporary work, the Mu tianzi zhuan 穆天子傳, described the shamanistic journeys of King Mu of the Zhou (r. 1023-983 BC), combining the Shanhai jing's exploration of mythical geography with an account of an individual's spiritual quest. A later romance about the Han ruler Wudi's (r. 140-86 BC) quest for immortality, Han Wudi neizhuan 漢武帝內傳 (ca. sixth century AD), developed one of the central themes of the $M u$ tianzi zhuan: both rulers' spiritual adventures involved revelatory encounters with the goddess Xi wang mu 西王母, the Queen Mother of the West and patron of the immortals. The worldly Han sovereign's initiation nevertheless ended in abject failure. ${ }^{3}$

The first veritable continuation of the Liexian zhuan was Ge Hong's 葛洪 (283-343) collection of Lives, the Shenxian zhuan 神仙傳. ${ }^{4}$ According to his preface, Ge's aim in compiling this work was apologetic: Having elsewhere in his writings adduced arguments of a philosophical and epistemological nature in support of the existence of immortals, he here relied on the weight and abundance of what he considered to be the historical evidence. As a result, his narratives tend to be more circumstantial than those in the Liexian zhuan. Another difference is ontological. In the Shenxian zhuan, the immortals' essentially human nature competes with the fantastic and mythical images traditionally attributed to their archaic ancestors. It is likely that Ge Hong's views on this question were influenced by a corresponding development in the cult of the immortals and immortality in Chinese society. ${ }^{5}$

The human nature of the immortals and their pervasive presence in the world of mortals highlighted the problem of recognition. A traditional motif, with reference to politico-religious discernment and prognostication, ${ }^{6}$ recognition became a key issue in encounter literature where postulants were scrutinized for marks of immortality and their ability to recognize an immortal, often in humble and unexpected guise, was in turn a sign of worthiness. One hagiographic collection was titled "Lives of Presumed Immortals" in acknowledgement of the uncertainty of recognition that was inherent in

2. See Max Kaltenmark, Le Lie-sien tchouan (traduit et annoté) [1953]. Revised reprint, Paris: École française d'Extrême-Orient, 1987.

3. See Kristofer Schipper, L'empereur Wou des Han dans la légende taoïste. Paris: École française d'Extrême-Orient, 1965.

4. See Fukui Kōjun 福井康順, Shinsenden 神仙傳. Tokyo: Meitoku, 1983; Gertrud Güntsch, Das Shen-hsien chuan und das Erscheinungsbild eines Hsien. Frankfurt a.M.: P. Lang, 1988.

5 . Cf. Chi-Tim Lai, "Ko Hung's discourse of hsien-immortality: A Taoist configuration of an alternate ideal self-identity" Numen 45 (1998): 183-220.

6. See Eric Henry, "The motif of recognition in early China." Harvard Journal of Asiatic Studies 47 (1987): 5-30. A version of the well-known Tang tale The Curly-bearded Stranger (Qiuran ke zhuan 虬客傳), about the physiognomic recognition of the predestined Tang ruler Li Shimin 李世民 (599-649), often attributed to Du Guangting, features as “Qiuxu ke 虬䰅客” in Shenxian ganyu zhuan (abbreviated SGZ below) 4.7b-10a. 
any intercourse across the boundaries of separate yet fundamentally similar categories of beings. ${ }^{7}$

By Tang times (618-907), Taoist hagiographic writing had evolved both in scope and degree of specialization. Lives of individual or associated saints, such as the Inner Biography of Recluse Tao Huayang, devoted to Tao Hongjing 陶弘景 (456-536), ${ }^{8}$ or the Lives of the Perfected Lords Wu and Xu of the Way of Filial Devotion, ${ }^{9}$ appeared in response to the development of scriptural movements or local cults. The circulation of many more than the number of “inner biographies 內傳” or “individual lives 本傳” that are presently extant can be inferred from references in other works. Antecedents of the individual biography included increasingly elaborate chronicles of the deeds and manifestations of the founding deities of Taoism, Lord Lao Emperor 黄帝, ${ }^{10}$ while at the same time collected lives also continued to be assembled in the tradition of the Liexian zhuan. The culminating medieval compilation of this kind was Du Guangting's massive Supplement to the Lives of the Immortals in forty scrolls. ${ }^{11}$

Some collected lives were organized according to thematic groupings (such as the Lives of Presumed Immortals already mentioned), or according to categories of immortals (e.g., the Lives of the Grotto-immortals), ${ }^{12}$ or again by region (Record of Jiang-Huai Saints)..$^{13}$ Motivated in part no doubt by the need to structure his sizeable output, the author of Encounters with Immortals created several new categories of thematic presentation. Thus one of Du Guangting's collections, Records of the Assembled Immortals of Yongcheng, ${ }^{14}$ grouped together the lives of female immortals as the entourage of the Queen Mother of the West; another assembled Lives of Immortals of the Wang Family, ${ }^{15}$ a courtly gesture towards the reigning house of the Former Shu (907-925) kingdom whose founder Wang Jian 王建 was Du Guangting's patron; yet another, Evidential Miracles in Support of Taoism, ${ }^{16}$ was constructed around

7. Yixian zhuan 疑仙傳 (9th/10th c.), by Yinfu yujian 隱夫王簡. Zhengtong Daozang 正統道藏 (below abbreviated as D) fasc. 151, no. 299 (here and below, fascicle and work numbers as in the Concordance of titles by Kristofer Schipper). In his prologue, the author speaks of his reluctance to apply the term "immortal 神仙" to his subjects outright (A.1a). Cf. Florian Reiter, "Studie zu den 'Uberlieferungen von mutmasslichen Unsterblichen' (I-hsien chuan) aus dem taoistischen Kanon." Oriens 29/30 (1986): 351-396.

8. Huayang Tao yinju neizhuan 華陽陶隱居內傳 (late Tang), by Jia Song 賈蔐. D 151, no. 300.

9. Xiaodao Wu Xu er zhenjun zhuan 孝道吴許二真傳 (9th c.). D 201, no. 449. Cf. Kristofer Schipper, "Taoist ritual and local cults of the $T$ 'ang dynasty." In Tantric and Taoist studies in honour of R.A. Stein, edited by Michel Strickmann, 3: 812-34. Brussels: Institut Belge des Hautes Etudes Chinoises, 1985.

10. Tang examples of these include the Taishang Hunyuan zhenlu 太上混元真錄 (D 604, no. 954) and the Guang Huangdi benxing ji 廣黄帝本行記 (881) by Wang Guan 王瓘 (D 137, no. 290).

11. The Xianzhuan shiyi 仙傳拾遺, still listed in Song catalogues but reported lost under the Ming. See the reconstitution of 100 of the original 429 lives in Yan Yiping 䲎一萍 ed., Daojiao yanjiu ziliao 道教研究資料, vol. 1, pt. 2. Taipei: Yiwen yinshu guan, 1974.

12. Dongxian zhuan 洞仙傳 (6th c.). See Yan Yiping, Daojiao yanjiu ziliao, vol. 1, pt. 1, and Li Fengmao 李䅱杯, Liuchao, Sui, Tang xiandao lei xiaoshuo yanjiu 六朝隋唐仙道類小説研究，187224, Taipei: Xuesheng shuju, 1986.

13. Jiang-Huai yiren lu 江淮異人錄, by Wu Shu 吳淑 (947-1002). D 329, no. 595. The region covered is that of the Jiang and Huai rivers, especially Jiangxi.

14. Yongcheng jixian lu 墉城集仙錄 (betw. 913-933). D 560-61, no. 783. Cf. Suzanne Cahill, Transcendence and divine passion: The Queen Mother of the West in medieval China, passim. Stanford: Stanford University Press, 1993.

15. Wangshi shenxian zhuan 王氏神仙傳. See Yan Yiping, Daojiao yanjiu ziliao, vol. 1, pt. 1, and F. Verellen, Du Guangting (850-933): Taoïste de cour à la fin de la Chine médiévale, 179-80. Paris: Collège de France, 1989.

16. Daojiao lingyan ji 道教㶾驗記 (betw. 905-933). D 325-26, no. 590. See F. Verellen, 
the motif of the miraculous corroboration 靈驗 of articles of faith experienced, or produced, by its subjects. Apart from any practical advantages of Du's method for dividing voluminous hagiographic materials into distinct collections, his encyclopedic categorization affords a rare glimpse into the structure of a medieval Taoist's conceptual universe. The following remarks about Du's Encounters with Immortals are made with that assumption in mind. Here we find a set of narratives that in many ways resemble those contained in the other collections just mentioned but were selected to exemplify the experience of direct contact with immortals serving as a vehicle for revelation and salvation. Stylistically, Du Guangting's records are akin to Tang "traditions of the supernatural," chuanqi 傳奇. The encounter was a recognizable topos even in largely secularized literary and artistic contexts. In the present article, we will be concerned with an element of the religious understructure of Chinese imaginative literature, the motif of mystical communion and revelation in the Taoist quest for encounters.

The Encounters with Immortals were completed in Sichuan early in the tenth century, probably not long after the year 904, during a fertile period in Du Guangting's literary career spanning the eclipse of Tang central authority and the consolidation of Wang Jian's regime in Shu. ${ }^{17}$ His sources were for the most part broadly contemporary, written and oral, ${ }^{18}$ and included Tang anecdotal writings and other traditional material. In the late tenth and early eleventh century, the Encounters with Immortals were extensively incorporated into two Northern Song imperial anthologies, the Taiping guangji 太平廣記 (987) and the Yunji qiqian 雲笼七籤 (ca. 1028). ${ }^{19}$ This ensured the text's circulation beyond its restricted distribution through the Taoist canon, and also the survival of a number of pieces that were subsequently lost from the main canon edition. The work was listed in a Song catalog as comprising ten scrolls (juan 卷); only five survive in the most complete edition extant today, in the Taoist canon of the Ming (1445). ${ }^{20}$ On the basis of these three fragments, we now dispose of ninety-three narratives from the Shenxian ganyu zhuan, representing slightly more than half of the original work..$^{21}$

\footnotetext{
“ 'Evidential Miracles in Support of Taoism:' The inversion of a Buddhist apologetic tradition in late T'ang China." T'oung Pao 78 (1992): 217-63.

17. The latest internal dates (4.4a-b and 4.5b) point to a completion after AD 904. On this period in the author's career, see Verellen, Du Guangting, 134-40 and idem, "Liturgy and sovereignty: The role of Taoist ritual in the foundation of the Shu kingdom (906-925)," Asia Major 3rd ser. 2. 1 (1989): $59-78$.
}

18. In some cases the informant is explicitly or implicitly named, e.g. in the stories "Deng Lao 鄧老”(1.13a-b), “Yang Chu 楊初” (1.13b-14a), “He Liang 何亮” (3.9b-10a), “Senior official Xue 薛長官” (3.10a-11b), and “Wu Shanjing 吳善經” (5.17a-18b). It may be noted that the legends leading to Du Guangting's own canonization in time attributed supernatural encounters to him as well. See Verellen, Du Guangting, 113-15 and 183-84.

19. See Taiping guangji, comp. by Li Fang 李昉 et al. (Zhonghua shuju ed.) juan 14, 15, 18, 19 , $22,24,29,33,43,46,53,54,64,65,75,378,394,420$, and Yunji qiqian, comp. by Zhang Junfang 張君房 (D 677-702, no. 1032), juan 112. Duplicates of individual stories in these anthologies will only be indicated to refer to specific textual variants.

20. See Song shi yiwen zhi 宋史藝文志 (1345) 4.5190, in Song shi 202-209 (Zhonghua shuju ed.). The principal Daozang edition is D 328, no. 592.

21. Eighteen are unique to the Taiping guangji; of these, three have multiple or doubtful attributions. 


\section{The quest for encounters}

The following story from the Shenxian ganyu zhuan illustrates well the devotional practice from which sprang the criterion for grouping the hagiographic material together in this collection: ${ }^{22}$

Xie Fan 謝璠 was a native of Shu 蜀川 (Sichuan) and a devotee of Taoism from youth. Having sworn a pact of brotherhood with two like-minded companions (tongzhi 同志), they set out together to roam the mountains in a wide search of recipes and techniques 方術. Thus, at the entrance to Emei shan 峨嵋山, they swore an oath together, saying: "This mountain is inhabited by immortals; it surely contains places for the quest of the Way 求道之所. The three of us shall part company here. Each will enter a different valley and observe whether there are any sightings 見遇 along his path." This said, they each went their separate ways.

Though the Taoist quest for encounters was often a solitary voyage, this passage attests to a spirit of community and brotherhood that bound "like-minded" pilgrims together. In another story featuring group travel to Emei, the only successful wayfarer is in the end, however, also separated from his companions. ${ }^{23}$ Another tale in the collection begins "The senior official Xue 薛 once set out from the capital together with a friend, a scholar named $\mathrm{Li}$ 李生, with the shared aim (tongzhi) of seeking the Way. They widely toured the great mountains..." - a phrase containing the same expression for comradeship and community of purpose, tongzhi, as our first example. ${ }^{24}$ Oaths and vows, important institutions in Chinese society and religion, clearly play a role in encounter stories: “The ten friends of Weiyang 維楊, all from well-to-do families, were men of integrity and moderation who venerated the Mysteries and knew the Way. They swore an oath of friendship and were like brothers to one another..."25

A key phrase in the introductory passage to Xie Fan's adventures is "This mountain ... contains places for the quest of the Way." We learn that a group of wandering brethren, in quest of esoteric initiation, have focussed their attention on a well-known holy site in Sichuan, reputed to be the dwelling of immortals. The systematic search for encounters naturally concentrated on the most likely locations: "Mount Ziluo is a supernatural domain of the immortals 紫邏山即神仙靈境也”26 or “Song, Luo and Zhenhua are all residences of immortals 嵩洛鎮華皆神仙之府, where one can live in peace and experience the Tao - no Taoist master can afford not to journey there."27 With such heightened prospects of a "sighting," the three friends set out to scour the mountain. And once again the brotherhood seals this mission with a separate oath. As they fan out, the narrative follows the hero of the story:

Fan entered Tree Bark Valley (Mupi gu 木皮谷). After five or six $l i$, he came upon 逢 four old men sitting together on top of a huge bolder. In front of them was a large pan in which meat was cooking. They were partaking of this together and, calling out to Fan,

22. “Xie Fan 謝璠," SGZ 4.1a-2a.

23. “Song Wencai 宋文才," SGZ 1.16b-17b. As in pilgrimage literature, the touristic element is also prevalent in encounter tales: In the Kaiyuan period (713-742), the unsuccessful jinshi candidate Wei Yan 韋畣 wanders in Shu (Sichuan). The season is pleasant, the sights lovely, and Wei and his friends undertake daily excursions in search of beauty and wonders 尋花訪異... (SGZ ap. Taiping guangji 33.209-210).

24. "Senior official Xue 薛長官," SGZ 3.10a.

25. “Weiyang shiyou 維楊十友," SGZ ap. Taiping guangji 53.328.

26. “Ziluo Ren sou 紫䢰任叟," SGZ 5.15a.

27. “Zhu Hanzhen 朱含貞” SGZ 5.16a. 
bade him sit down. They greeted him and invited him to eat of the meat. Fan told them: "Having set my mind on following the Way of the immortals, I have wandered the great mountains and have long abstained from pungent and bloody foods 莗血, never daring to lapse." The old men were pleased and said: "Since you seek the Tao 求道, you need only enter this valley where you are bound to have an encounter 當有所遇."

Fan then went into the valley. When he had traveled several tens of $l i$, he made out a magnificent belvedere 臺閣. When he reached it, it was not a dwelling in the world of mortals. Entering the gate, he saw several Taoist masters. They asked him how he had got there, and he gave them a detailed account. One of them looked at Fan attentively for a long while, then led him up into the great hall. There stood a majestic statue of the Celestial Worthy (Tianzun 天尊), in front of which lay a pile of scriptures on a table. Fan's guide told him to close his eyes and select a scroll at random. He then bestowed it on Fan, saying: "This is a celestial writ in large seal characters 大管. If you practice it you should be able to attain long life and salvation, to accumulate merit and save others. This is not a place for you to linger. You should leave now." Fan bade farewell to the Taoists, took his scripture, and left the mountain.

This section, too, evokes several themes that are characteristic of the genre and its underlying religious conceptions. A first meeting takes place where Fan must pass a test before learning that the encounter sought, and already hopefully expected, was indeed certain to occur. As in other religions, trials form part of Taoist initiatory rites. The seven trials to which Zhang Daoling 張道陵 (second century AD) subjected his disciples feature among the founding myths of Heavenly Master Taoism. ${ }^{28}$ The Shenxian ganyu zhuan demonstrates that resolute vegetarianism was a sine qua non for any adept, lay as well as clerical, seeking an encounter. In another story set at Mount Emei, the monk and indefatigable pilgrim Wuxuan 悟玄 — "though he had donned the Buddhist habit, he was devoted to the quest of the Way" — is enjoined by a first encounter, an "old man 鼠," to seek further instructions from the "grotto warden 洞主," a middle-aged, corpulent butcher named Zhang in the market of nearby Jiazhou 嘉州 (modern Leshan). Zhang has his wife prepare several meat dishes which he presses on Wuxuan as necessary sustenance for entering the sacred mountain. Although Wuxuan suspects a test by an immortal 神仙所試 in disguise, he cannot bring himself to disobey the warden and finally succumbs to his host's urging. After having been plied with meat and drink, he is allowed a glimpse of the divine grotto but ultimately fails in his quest. ${ }^{29}$

To return to Xie Fan: After his steadfast refusal of the old men's meat dish and having reached the dwelling of the immortals, a second qualifying trial, in the form of a physiognomic examination, allows him to proceed to the sacrosanct great hall. The realm of the immortals, though recognizable from the outside, is separated by a clear boundary: the gate; Fan's alien presence on the other side is not tolerated beyond a certain interval. Finally, the object of Fan's quest is revealed: a divine text, characterized by archaic writing and endowed with saving power. Its use and efficacy are the subject of the remainder of the story, which also throws some light on the range of Xie Fan's patrons:

When [Fan] reached the mouth of the valley, he stayed overnight in the home of a family of the people. They had a small child who had fallen into boiling water and was scalded all over. The whole family was in a state of fearful sorrow, unable to save the

28. Shenxian zhuan ap. Yunji qiqian 109.19a-21a. Cf. F. Verellen, "Zhang Ling and the Lingjing salt well," in En suivant la voie royale: Mélanges en hommage à Léon Vandermeersch, edited by Jacques Gernet and Marc Kalinowski, 249-50. Paris: École française d'Extrême-Orient, 1997.

29. “Seng Wuxuan 僧悟玄," SGZ 5.11b-12b. 
child. Fan had seen an annotation in the celestial writ to the effect that it could bring about cures. Thus he wrote out the text and blended it with water ${ }^{30}$ with which he washed [the patient]. After a short while the child was completely healed. From then onward he frequently saved others by means of the hidden merit of the celestial writ. Innumerable were those who benefited from its efficacy.

When the chief minister and commandant Duke of Bin 四公 (Du Cong 杜悰) ${ }^{31}$ assumed the command of Chengdu (in AD 848), ${ }^{32}$ he summoned Fan as his retainer and treated him with extraordinary deference. When the duke went to the capital for an audience at court, Fan also followed him to Chang'an. One day, one of the children of the duke of Bin fell severely ill. None of the imperial physicians were able to cure it. Suddenly the duke remembered the power of Fan's divine seal script and had him urgently summoned. As soon as [Fan] arrived, he took up a brush, wrote out [the text], and the child was cured. [The duke] bestowed on him more than a hundred thousand in gold and silk currency, but [Fan] accepted none of it. After that he returned to Shu and resumed his wanderings in the mountains. It is not known where he went.

The salutary effect of the divine writ resides in the first place in its magical healing power. At the same time, however, it allows Xie Fan to acquire personal merit by coming to the aid of others. His own salvation, then, is ultimately due to a form of karmic merit accumulation, made possible by the conferral of a supernatural text. The end of the story suggests that he joined the ranks of the immortals, roaming the world now as immortals do.

\section{Taoist Thresholds}

The words ganyu 感遇 in the title Shenxian ganyu zhuan can be translated as "supernatural encounter." Meaning literally responsive or interactive encounter, the term is suggestive of threshold situations on the boundary - line of both separation and contact - between the discrete spheres that were occupied by men and immortals. In Tang thought, the "bounds of spirits and men 神人之祭" were paradoxically defined by the tension between two archaic and contradictory notions: In the first place, the gulf separating distinct species or categories 類, such as animal and human, male and female, heaven and man, the living and the dead, could not be bridged. ${ }^{33}$ Against this, however, the ganying 感應 theory postulated a relationship of "stimulus and response" between separate spheres, explaining the occurrence of rare phenomena and their moral significance. The ancient debate between the proponents of responsive cosmology and its skeptics continued in Tang intellectual circles and had repercussions on contemporary interpretations of the place of the supernatural in human affairs. ${ }^{34}$ To the authors of Tang mirabilia and the "transmitters of marvels 傳奇," or "recorders of

30. Referring to the ashes after burning the text. This was the method of preparing $f u$ 符 talismans for ingestion, aspersion, and other applications.

31. See Jiu Tang shu 舊唐書 (945) 147.3984-86 and Xin Tang shu 新唐書 (1060) 166.5090-92 (Zhonghua shuju ed.). The name of Du Cong's fief was also written Bin 那.

32. See Wu Tingxie 吳廷隻 (1866-1947), Tang fangzhen nianbiao 唐方鎮年表 6.980. Peking: Zhonghua shuju, 1980.

33. Cf. Confucius, Analects 18.6: "The Master said: We cannot join the flocks of birds and beasts. If I may not associate with mankind, then what am I to be?" Yang Bojun 楊伯峻 ed., Lunyu shizhu 論語譯注, 18.194. Peking: Zhonghua shuju, 1980.

34. See H.G. Lamont, "An early ninth century debate on Heaven: Liu Tsung-yüan's T'ien Shuo and Liu Yü-his's T'ien Lun (1-2).”'Asia Major n.s. 18 (1973): 181-208 and 19 (1974): 37-85. 
wonders 志怪” as their Six Dynasties predecessors were called, traversing the boundaries between the purportedly hermetic spheres was an abnormal but not inconceivable eventuality, providing an absorbing subject for speculation and source of wonder. ${ }^{35}$

The relation between the different spheres was not only a matter for rational debate, but also a question of faith, and an object for skilled manipulation by specialists. If the fate of man was subject to the will of gods, religion and magic wielded efficacious instruments to sway those gods: sacrifices, rituals, prayers, and other "techniques 方術." The Shenxian ganyu zhuan, while placing the emphasis on devotional commitment and merit, ${ }^{36}$ as well as acknowledging the factor of chance or "good fortune," is concerned with the efficacy of all such methods for breaching the barrier between this world and the beyond. ${ }^{37}$

The Taoist threshold par excellence was the grotto 洞, situated inside the sacred mountain. Passages between worlds, microcosms, and dwellings of immortals, grottoes featured inversions of time, space, darkness and light, outside and inside, above and below that defied the laws of nature or replicated them in separate systems. They were favored places for encounters, for obtaining the rare metals and minerals needed for alchemical preparations, and for discovering secreted texts. ${ }^{38}$ The topography of the places of transit was evanescent: they would suddenly reveal their location, then vanish just as mysteriously. The concept of the transcendent grotto, essentially a meditational device, had a correspondingly ambivalent status as a place of ascetic practice and physical encounter, a mental projection of idealized ritual space, and a metaphor of transcendence. The crossing of this threshold could accordingly be accomplished through actual travel, through meditation and other mental and physical disciplines, or through dreams and visions. Not surprisingly, quite a few encounter stories in the Shenxian ganyu zhuan are set in the conceptual world and idiom belonging to the mythology of transcendent grottoes. ${ }^{39}$

The meaning "response" of the word gan 感 in ganyu points up the interactive nature of the encounter. The process is made explicit in some stories by means of a trigger event, a device for bridging the gap or breaking through the barrier between the unseen world and that of phenomenal perception. The stimulus can be a sudden sensation - light, sound, fragrance - or the irruption of numinous power in nature landslides, unusual meteorological phenomena, inspired animal behavior:

Guo Ziyi 郭子儀, ${ }^{40}$ before attaining eminent rank and a ripe old age towards the end of the eighth century, serves in the military in the [Inner Mongolian] desert. One evening,

35. See Glen Dudbridge, Religious experience and lay society in T'ang China: $A$ reading of Tai Fu's Kuang-i chi, 19-23 (Cambridge: Cambridge University Press, 1995) and Verellen, Du Guangting, 173-77.

36. Including the Buddhist-inspired notion of karmic reward: "That today you obtained an encounter with me, is the result of an accumulation of merit 今得值我已是積善斦鐘矣” (SGZ 5.17a).

37. Ritual: “Cui Xuanliang 崔玄完” (1.8b-9b), “Taoist Qian 錢道士”(1.9b-10a); prayer: “Taoist Wang Zuan 道士王策” (SGZ ap. Taiping guangji 15.103-104), "Zhang Shiping 砖士平” (SGZ ap. Taiping guangji 75.469-70); magic: “Li Ji 李岁”(1.3a-b), “Wang Zizhi 主子芝” (3.8a-9b).

38. See F. Verellen, "The Beyond within: Grotto-heavens (dongtian 洞天) in Taoist ritual and cosmology." Cahiers d'Extrême-Asie 8 (1995): 265-90.

39. See “Song Wencai 宋文才” (1.16b-17b); “Chen Jian 陳簡” (2.3a-b); “Wu Pan 吳磻” (2.4b$5 b)$; “Scholar Wang 王生” (2.5b-6a); “Li Yan 李顔” (2.9b); “Li Ban 李班”" (2.9b-10a); “Wang Kuo 王廊”(5.4a-b); “Xue Feng 薛逢”(5.7a-8b); “Shu min 蜀民” (5.8b-9b); “Seng Wuxuan 僧悟玄” (5.10b-12b); “Wu Shanjing 吳善經” (5.17a-18b); “Wen Guangtong 文廣通” (SGZ ap. Taiping guangji 18.125-26); “Ershiqi xian 二十七仙” (SGZ ap. Taiping guangji 29.188-89).

40. A distinguished loyalist general during and after the An Lushan rebellion (755-757). See 
while journeying back to the capital on army business, a sandstorm plunges the travelers in sudden darkness near Yinzhou 銀州 (modern Mizhi, in Northern Shaanxi). Guo finds shelter in a deserted roadside house. After nightfall, he is suddenly engulfed by a red luminosity. Looking up, he sees a beautiful maiden descending from heaven... ${ }^{41}$

Peng Qiu 蓬球 was a native of Beihai 北海 (Shandong). In the Taishi reign period (265-275) of the Jin dynasty, he had entered Mount Jade Maiden 玉女山 to the west of Juqiu 具丘 (Shandong) to cut trees when he suddenly perceived a strange fragrance 異香. As he went against the breeze in search of its source, the mountain suddenly opened wide on a sprawling palace complex with lofty terraces. Qiu entered and looked inside. He saw five jade trees and, advancing further, four female immortals playing chess at the upper end of the hall. When they saw Qiu, they all rose in surprise and said: "Mr. Peng, how did you get here?" Qiu said: "I followed the fragrance and arrived here..." 42

... One day a merchant named Li Shun 李順 moored his boat beneath the dam at Jingkou 京口 (modern Zhenjiang, Jiangsu). Late at night, the anchor stone became detached and the boat drifted away out of control. The next morning it had come to a stop beneath a mountain. When the wind and waves had abated, $\mathrm{Li}$ went ashore to make enquiries. After proceeding for five or six $l i$ along a small mountain path, he beheld a man of extraordinary appearance, wearing a black turban 鳥巾 [in the manner of recluses] and archaic vestments. He led Li Shun up the mountain where they came to a supernatural palace... ${ }^{43}$

In the year AD 449 under the Liu Song dynasty, Wen Guangtong 文廣通 of Chenzhou 辰州 (modern Qianyang, Hunan) shoots a boar feeding on his grain seed. The boar gets away, leaving behind a trail of blood. Guangtong follows the trail to a grotto. Inside it, he finds a human settlement. An old man emerges to ask him whether he had shot his pig. Guangtong replies that he had acted in legitimate self-defence... Then he is led to a hall filled with clerks and scholars, including the Daode jing commentators Heshang gong 河上公 (Later Han?) and Wang Bi 王弼 (226-249)...44

Denis C. Twitchett, ed., Sui and T'ang China, 589-906: The Cambridge History of China, 3.1: 456-61. Cambridge: Cambridge University Press, 1979.

41. Synopsis, SGZ ap. Taiping guangji 19.131-32. Since the date is the Double Seventh midsummer festival, Guo concludes that it must be the Weaving Maiden 織女, come to bestow blessings on him.

42. Synopsis, SGZ 2.1 a-b. This story, which also appears in Yunji qiqian 112.9b-10b, is textually close to and may be borrowed from the slightly earlier version in Duan Chengshi's 段成式 (ca. 803863) Youyang zazu 酉陽雜㸖. The latter is reproduced in Taiping guangji 62.389. On supernatural fragrance associated with grottoes, see also “Wu Pan 吳磻” (SGZ 2.4b-5b), a story about the aromatic properties of the lustrous wenshi 文石 stone when heated, and "Wang Kuo 王邡" (SGZ 5.4a-b), about fragrant "celestial wine" discovered in a grotto at Junshan (cf. below).

43. Synopsis from SGZ ap. Taiping guangii 19.132-33, a story about the Tang chief minister and governor of Zhexi (Zhejiang) Han Huang 韓滉 (723-787; see Twitchett ed., Sui and T'ang China, Cambridge History 3.1: 591-92). Li Shun is commissioned to transmit an ancient scroll to Han in order to correct the governor's "overbearing and self-satisfied character." After a ceremonious hand-over, $\mathrm{Li}$ is escorted back to his boat and informed that "This is Mount Guangsang 廣桑山 in the Eastern Sea 東海 where Xuanfu Zhongni 宣父仲尼 (Confucius) of the Lu kingdom carried out his administration upon attaining the Way and becoming a true official 真官. Lord Han is in fact Zhongyou 仲由 (the disciple of Confucius better known as Zilu 子路). This book is intended to instruct him..." The boatmen are then told by an angel 使者 to sit still and fear not while the boat hurtles with supernatural speed back to Jingkou.

44. Synopsis, SGZ ap. Taiping guangii 18.125-26. This story belongs to the Buddho-Taoist literature on retribution for injuries caused to animals (cf. "Ruan Ji 阮基," SGZ ap. Taiping guangji 
The significance of the apparently fortuitous nature of these encounters is subtly shaded by the action of the trigger event which suggests, on the contrary, the deliberate working out of the will of nature or divine providence. In the last example, the boar seems at first sight to lead the hapless sinner to his underworld judge by randomly seeking refuge in a grotto; but when it turns out - despite the appellation "wild boar 野豬" - to belong to one of that world's denizens, the whole sequence of events takes on an appearance of being predetermined. In a similar tale the subject is led by his obstinate mule, ostensibly in search of greener pastures, into the mouth of a supernatural grotto. Perceiving light in the depths of the grotto and walking towards it, he eventually emerges into another world. There he learns that the mule had in fact been remote controlled by the immortal elder of the grotto in order to arrange an encounter, in view of his daughter's predestined marriage with the hero. ${ }^{45}$ The implication is that, in addition to merit and chance, Taoists considered the work of salvation and sanctification to depend upon a kind of gratuitous, spontaneous gift, resembling the idea of grace in Christian theology.

\section{Revelation, transmission, and initiation}

Medieval Taoism was an esoteric teaching largely based on revelation. It observed graded procedures for the initiation of its followers, including laymen, and for the transmission of its scriptures. Revelation, ultimately a cosmic manifestation, though transmitted through a variety of agents and intermediaries, typically involved the spontaneous formation of written characters. To Taoists, calligraphy was a divine art. Scriptures and magical writings, especially in the form of $f u$ 符 talismans and seals, were considered efficacious independently of their content. ${ }^{46}$ Taoist ordinations were systematically tied to textual transmission, each ordination degree corresponding to initiation into a specific level of the hierarchically structured canon. ${ }^{47}$ Despite such shared institutional features, however, the Taoist community remained multipolar, with little sense of centralized ecclesial authority. As a liturgical organization, Taoism was closely involved with local cults and sacred sites across China. Seeking instruction from

15.107-108, and Verellen, “Evidential Miracles,” 238-40). The text names Wuling ji 武陵記 as its source. At least two works bore this title, attributed to Huang Min 黄閔 of the Southern Qi (479-502) and to Wu Anpin 伍安貧 of the Liang (502-557), respectively. A slightly different version of the same tale also found its way into the Guangyi ji 廣異記 (8th c.), ap. Taiping guangji 39.248-49. Cf. Qian Zhongshu 錢鐘書, Guanzhui bian 管錐編, 662 (Peking: Zhonghua shuju, 1979) and Dudbridge, Religious experience, 176. In “Ershiqi xian 二十七仙, ” SGZ ap. Taiping guangji 29.188-89, a white rabbit triggers the discovery; in the chuanqi tale "Liu Yi zhuan 柳毅傳" (late 8th c.), by Li Chaowei 李朝威, a bird takes to the air, causing the traveler's horse to bolt in the direction of his encounter. See Zhang Youhe 張友鶴 ed., Tang Song chuanqi xuan 唐宋傳奇選, 23. Peking: Renmin wenxue chuban she, 1979.

45. “Cui sheng 雀生,”Yishi 逸史 (pref. 847), by Lu Zhao 慮肇, ap. Taiping guangji 23.154-56. See the translation in F. Verellen, "Luo Gongyuan: culte et légende d'un saint taoïste." Journal Asiatique 275 (1987): 322-27.

46. See Laszlo Legeza, Tao magic: The secret language of diagrams and calligraphy, London: Thames and Hudson, 1975, and Michel Strickmann, "The Seal of the Law: A ritual implement and the origins of printing," Asia Major 3d ser. 6. 2 (1993): 1-83.

47. See Kristofer M. Schipper, "Taoist ordination ranks in the Tunhuang manuscripts," in Religion und Philosophie in Ostasien: Festschrift für Hans Steininger, edited by Gert Naundorf et al., 127-48. Würzburg: Königshausen \& Neumann, 1985. 
renowned masters and recluses, and inspiration in remote holy places, were recognized methods of spiritual advancement. Indeed, the texts discussed below suggest that the quest for encounters offered prospects of mystical communion and direct revelation that, while not necessarily bypassing the temple, the canon, and the priest, complemented their institutional roles.

What were the objectives of the transmission sought in encounters, and the objects transacted? Texts, in the form of scriptures, formulas, and talismans for longevity or healing, were undoubtedly the most important vehicles of revelation and instruments for acquiring merit. In that context, the magical acquisition of literacy becomes a potent tool for salvation. Features of China's medieval book culture and the value attached to learning are woven into the texture of the Shenxian ganyu zhuan and take on a religious coloring there: In the story of monk Wuxuan 僧悟玄 cited above, the old man encountered at Mount Emei explains the need to obtain and diligently study books with titles like Record of [Lake] Grotto Court (Dongting $j i$ 洞庭記) and Classic of Peaks and Waterways (Yuedu jing 狊瀆經) as a prerequisite for finding the dwellings of immortals and avoiding harm in the demon-ridden mountains. ${ }^{48}$ The old man Ren of Mount Ziluo 紫邏任鼠 mysteriously appears in a medicine shop in Ruzhou 汝州 (modern Linru, Henan) and asks for writing materials before ceremoniously composing and transmitting a prophecy concerning a customer in the shop. ${ }^{49}$

The efficacy of writing and the "textuality" of revelation are strikingly illustrated by the following story: ${ }^{.0}$

Chen Jian 陳簡 was a minor official in Jinhua county 金華縣, Wuzhou 整州 (Zhejiang). Once he arrived at the county seat at dawn, ${ }^{51}$ before the gates had been opened. Waiting irresolutely, he suddenly encountered a Taoist 道流 who was walking along very swiftly. The latter cast a sidelong glance at Jian, whereupon Jian followed him involuntarily. After they had walked for three or five $l i$, they arrived at a palatial temple soaring against the side of a great mountain. The Taoist led him into a dark $\mathrm{k}^{52}$ chamber which contained a low table with brushes, ink, and the like. Taking a yellow silk script 黃素書 (i.e., a Taoist writ) in one scroll comprising more than ten sheets of paper, he gave it to Jian, saying: "You are a man of letters 汝有書性. Write this out for me." On opening and examining the scroll, he found that it was entirely in ancient seal script 篆. Jian had never been able to read seal characters, nor had he ever been a particularly diligent student. He felt most apprehensive. Before he could decline, the Taoist had already disappeared. However, when he tried copying the characters out from the book he found it very easy. In half a day it was done.

The Taoist gave him a cupful of a beverage, saying: "This is the nectar of Jinhua 金華神液. It must not be taken heedlessly. Those who obtain to drink of it live forever." Its taste was pleasantly sweet. Then the Taoist dismissed him, saying: "In times of difficulty come back here. This is the Jinhua Grotto-heaven 金華洞天." 53 Once outside, he felt dazed as if waking from a dream. Three days had already passed. After he returned home, he applied himself to writing seal script. His brush became uncommonly vigorous and he stopped eating and drinking. The prefect $\mathrm{Xian} \mathrm{Zi}$ 鮮梓, who was then just about to receive

48. SGZ 5.11b. The specific injunction to study the exact names of places and demons in such works echoes a theme in the Baopu zi neipian 抱朴子內篇 by Ge Hong 葛洪 (283-363). See Wang Ming 王明 ed., Baopu zi neipian jiaoshi 抱朴子內篇校釋 17.273-95. Peking: Zhonghua shuju, 1980.

49. SGZ 5.15a-b.

50. SGZ 2.3a-b; ap. Yunji qiqian $112.11 \mathrm{~b}-12 \mathrm{~b}$.

51. Yunji qiqian has zao 早, "early," instead of dan 且.

52. Dark: omitted in Yunji qiqian.

53. No. 35 of the Lesser Grotto-heavens. See Verellen, "The Beyond within," Appendix; Li Xiaoshi 李曉實, “Zhongguo daojiao dongtian fudi lansheng 道教洞天福地攬訪”, 193-96. Hong Kong: Haifeng, 1993. 
a Taoist ordination, marveled at this and believed that [Chen Jian] was an immortal. The happy miracle was formally announced 判縣. The memorial read...

Chen Jian's "uncommonly vigorous brush" recalls the famous calligraphy of the visionaries and early transmitters of the fourth-century Shangqing 上清 revelations whose inspired art influenced two patriarchs of Chinese calligraphy, Wang Xizhi 王羲之 (303-361) and his son Wang Xianzhi 王獻之 (344-388), and served the scriptural scholar Tao Hongjing 陶弘景 (456-536) as a criterion for determining the authenticity of Shangqing autographs. ${ }^{54}$

Wu Shanjing 吳善經, whose given name means “proficient in scripture," had for more than ten years "carried out an extensive search for grotto-residences and covered the secluded sights all round 博器洞府, 周歷幽勝. " Eventually, he discovers a grotto inhabited by immortals. Having paid obeisance, Shanjing declares his good fortune in having made the encounter and begs for instruction for prolonging his life-span and attaining salvation. He is given a scroll which would not save him directly but endow him with the discernment to "fully expound holy scripture and attain proficiency in the “jade script 玉字' (i.e., contents) of celestial writs." With this ability he is to assist the emperor and thereby increase his own merit. The immortal...

...then made him read [the text]. Since Shanjing was unable to make out any of it, the immortal bestowed his teaching on him with repeated, careful instructions. Shanjing's understanding underwent a sudden illumination and he comprehended every detail... From then on, he could read the jade seal characters and red script and the precious writs and esoteric instructions 玉管赤書寶章真訣 in the scriptures with perfect familiarity, exactly as if they had been in clerical script 隸書...5

Arcane texts, meanwhile, are not the only objects for transmission in Encounters with Immortals. Another distinct category comprises substances for ingestion, especially drugs such as cinnabar 丹 $^{56}$ and items of food and drink conferring longevity and immortality. ${ }^{57}$ The latter include the Jinhua "nectar" already encountered, a chestnut, a peach, wine, the hand-shaped rouzhi 肉芝 fungus, wheat meal, as well as unspecified foods:

Wang Kejiao 王可交 ${ }^{58}$ was a native of Kunshan 芘山 [county] in Suzhou 蘇州 prefecture (Jiangsu). He was a peasant by origin and had no initial knowledge of the Way. When he was a few years old, his eyes developed a divine luminosity 五色光. It became more intense when he got up at night, enough to reflect from objects in the dark room. Someone said to his relatives: "This is a disease. Once the luminosity is exhausted, he will

54. See Michel Strickmann, "The Mao Shan revelations; Taoism and the Chinese aristocracy." T'oung Pao 63 (1977): 1-64; Lothar Ledderose, "Some Taoist elements in the calligraphy of the Six Dynasties." T'oung Pao 70 (1984): 246-78.

55. SGZ $5.17 \mathrm{a}-18 \mathrm{~b}$. The remainder of the text relates that $\mathrm{Wu}$ subsequently embarked on a court career as prophesied. Up to the Huang Chao rebellion (881), he belonged to the same Taoist circles in Chang'an as Du Guangting; he would appear to be the likely source for this story.

56. See e.g. “Reverend Master Feng 豐尊師” (1.15b-16b); “Chief minister Lu Jun 相國盧鈞” (3.6a-7b); "He Liang 何亮” (3.9b-10a); “Taoist Lu 盧道流” (4.4a-b); and "Scholar Cheng 成生” $(4.4 \mathrm{~b}-5 \mathrm{~b})$.

57. The ingestion of medicinal or magical substances was in some cases also linked with textual transformations: $f u$ 符 talismans were written as well as swallowed.

58. SGZ 2.1b-2b. Wang Kejiao was a well-known Taoist figure at Mt. Tiantai; see Tiantai shan fangwai zhi yao 天台山方外志要, compiled by Qi Shaonan 齊召南 (pref. 1767) 7.6a. Revised edition by Ruan Yuan 阮元 (pref. 1802). 
lose his eyesight." His parents in their ignorance called a sham physician to administer moxibustion to him. The luminosity then stopped. ${ }^{59}$

In the eleventh month of the year Xiantong $10(869),{ }^{60}$ Kejiao was returning home from the market when he saw a large pleasure boat on the river. Decked with golden silk embroideries and richly adorned with pearls and jades, it was floating along to the strains of music. As Kejiao stood and looked at it, the boat pulled up to the embankment. There was a Green Lad 青童 ${ }^{61}$ in it who led him onto the boat. There he saw some ten people wearing high caps and feather garments 峨冠羽服, the mottled patterns of their vestments resembling auroral cloud landscapes. Each was holding a musical instrument. One of them called out to him: “Uncle Five-three 五三叔 wishes to see you; and we don't know where you're from!" A person beside him said: "Good immortal's bones, but damaged by fire! He can't yet be given wine. ${ }^{62}$ Only after he has abstained from food for ten years will he be able to obtain the Way." With this, he handed him a single chestnut 采子, instructing him to eat it. Kejiao ate one half and kept the other half in his hand. After that, the music struck up and they drank the wine while the boy conducted him back to shore. As if in a dream, his feet only touched ground again when he had dropped beneath Waterfall Cliff 瀑布㩔 ${ }^{63}$ at Mount Tiantai 天台山 (Zhejiang), [having traveled] a thousand $l i$ over land and water in an instant.

The monk Huaiyi 僧懷一, in a story set in the Xiantong reign period (860-874), obtains a "peach of immortality 仙桃” from a passing Taoist. ${ }^{64}$ In the same reign period, Wang Kuo's 王廓 boat is tossed against the shore beneath Mount Junshan 君山 on Lake Dongting in a storm. Perceiving the fragrance of wine and following it into a grotto, he discovers a reservoir of "celestial wine 天酒" there in the hollow of a rock. Drinking the wine confers immortality. ${ }^{65}$ The ten friends of Weiyang (see above) are invited by a mysterious old man to a banquet to reciprocate their kindness. The food confers bodily immortality and they all ascend into heaven together. ${ }^{66}$ Xiao Jingzhi 蕭靜之 suddenly loses his hair and teeth and believes he is haunted by the Taisui spirit 太歲神. One day he finds a rouzhi 肉芝 fungus in the ground. After eating it, his hair and teeth grow again. A Taoist explains that he had eaten an "immortal drug 仙藥” capable of conferring the longevity of cranes and tortoises. ${ }^{67}$

Apart from the general aims of attaining immortality or increased longevity, some more particular objectives can be identified in the transactions taking place on the occasion of encounters. One is the related aim of healing. In this and other examples it takes the form of preserving or restoring an individual's health or bodily integrity:

59. For another example of this condition and its mistaken treatment, see the story "Chi Fazun 郗法道" in the same author's Luyi ji 粶罢咭 (ca.921-925), D 327, $\mathrm{n}^{\circ}$ 591, 2.7a-b.

60. A more elaborate version of the following episode is found in the Xu xian zhuan 續仙傳, by Shen Fen 沈汾 (fl. ca. 937-975), D 138, no. 295, B.13a-15b; this source is cited as Xu shenxian zhuan 續神仙傳 in Taiping guangji 20.136-38.

61. This deity, associated with revelation, frequently appears as the guide of dreamers and visionaries. See Paul W. Kroll, "In the halls of the Azure Lad." Journal of the American Oriental Society 105 (1985): 75-94.

62. In the $X u$ xian zhuan version, the supernatural wine refuses to be poured from its ceremonial vessel for Wang Kejiao.

63. Xu xian zhuan: "in front of Waterfall Monastery 瀑布寺."

64. SGZ 5.1b-2b.

65. SGZ 5.4a-b.

66. SGZ ap. Taiping guangji 53.328-29.

67. SGZ ap. Taiping guangji 24.162-63. For rouzhi, see also Ge Hong, Baopu zi neipian jiaoshi 抱朴子內篇校釋 11.178. On possession by Taisui, see Hou Ching-lang, "The Chinese belief in baleful stars," in Facets of Taoism, edited by H. Welch and A. Seidel, 193-228. New Haven: Yale University Press, 1979. 
The Tang Prefect of Shouzhou 薵州 (modern Shouxian, Anhui), Zhang Shiping 張士平 and his wife have been afflicted by blindness from middle age. Having repeatedly and to no avail sought a cure by means of the arcane arts and skilled techniques 方術, they withdraw to a private mansion. Cutting themselves off from the world and assuming the blame [for their misfortune], they pray and sacrifice steadfastly to the stars 禱醮星辰 to beg for divine assistance. On the seventeenth day of the eighth month of the year Yuanhe 7 (812), a scholar 書生 appears at the gate, insisting to be admitted. He instructs the household to sink a well and with the new water washes his hosts' eyes and heals their blindness. Refusing all recompense, he declares: "I am not a being of this world, but an official of the planet Venus 太白星官. Because you remained mindful of the Tao during the years you suffered your disease, and wholeheartedly prayed and sacrificed, you moved 感 the stars above and the Five Emperors Lords of the Planets 五帝星君 sent me below to bestow this technique in response to your devotion." He then leaves the water healing method and an almanac for using it in aid of others. ${ }^{68}$

Elsewhere the text is concerned with public health. The Reverend Master Feng 豐尊師, for example, a follower of Heavenly Master Ye Fashan 葉法善 (d. 720) in Chuzhou 處州 (Zhejiang), obtains a drug and a divine sword 神劍 to save victims of an epidemic. ${ }^{69}$ Other stories attribute disaster relief in times of war and drought to encounters, as well as alleviation of the sufferings caused by banditry, poverty, and famine:

Yang Chu 楊初, a member of the guild of gold and silver smiths in the East Market at Chengdu 成都 (Sichuan), finds himself ruined by a crushing military tax during the siege of the town [by Wang Jian 王建] in 890-891. Thanks to Yang's veneration of an image of the immortal Luo Gongyuan 羅公遠, however, the saint makes an apparition and solves the gold smith's fiscal problem by transforming pig iron into gold. ${ }^{70}$

Liu Yanguang 劉彥廣, a native of Jinling 金陵 (Jiangsu), is employed in the service of Zhexi (Zhejiang) military governor Tang Ruoshan 唐若山. ${ }^{71}$ Tang and his brother Ruoshui 若水 are Taoists who had both experienced encounters with immortals 遇神仙 and received their instruction. During the Kaiyuan reign period (713-742), Ruoshan leaves his post and disappears. Yanguang runs into him ten years later carrying and selling fish at the fish market in Yangzhou 楊州 (Jiangsu). Ruoshan turns pig iron into gold for him, to pay his government dues and create wealth for himself and his descendents, then enjoins him to quit his career and seek the Tao by studying scripture. ${ }^{72}$

Here the granting of cures and relief from suffering are again subsidiary to the goals of attaining immortality and longevity since charitable work provided opportunities for merit accumulation. The logic of this practice was inspired by the Buddhist theory of karmic causation and the bodhisattva ideal, both current in medieval Taoism. ${ }^{73}$ However, the eminently pragmatic concern underlying encounters of the gold-making

68. Synopsis, SGZ ap. Taiping guangji 75.469-70. In the same vein, see also "Cui Yan 崔言," SGZ ap. Taiping guangji 75.474 .

69. SGZ 1.15b-16b. On Ye Fashan and the Zhejiang background to this story, see Verellen, $D u$ Guangting, 9-16.

70. Synopsis, SGZ 1.13b-14a. On Yang Chu, possibly an acquaintance of Du Guangting, see also Daojiao lingyan ji 9.6b-7a; cf. Verellen "Luo Gongyuan," 307-308.

71. Cf. Jiading Zhenjiang zhi 嘉定鎮江志, by Lu Xian 盧害 (early 13th century), 14.6a (Jinling edition of 1910) and Qinding Quan Tang wen 欽定全唐文 (pref. 1814), compiled by Dong Gao 董誥 et al., 395.26a (Taipei 1961 facsimile of 1814 Palace edn.).

72. Synopsis, SGZ 1.14b-15a.

73. See Verellen, "Evidential Miracles," 233-43. 
kind, ${ }^{74}$ where the wealth generated is destined for the fulfillment of obligations, the livelihood of the subject's descendants, or material freedom to devote himself to religious pursuits, seems entirely Chinese and Taoist.

Finally, the revelatory message of encounters can also have the effect of confirming tenets of doctrine about the unseen world, for example the nature of the pantheon or the efficacy of ritual, and of authenticating scriptures, iconic representations, etc. Its apologetic tenor establishes a parallel between this type of encounter hagiography and the "evidential miracle tale 靈驗記."75 An example is the following encounter with the Lord of Thunder, an early record of the antecedents of thunder magic and ritual developed under the Song: ${ }^{76}$

Ye Qianshao 葉遷韶 77 was a native of Xinzhou 信州 (Jiangxi). In his youth, while gathering firewood, ${ }^{78}$ he once sought shelter from the rain under a tree. Suddenly he saw the Lord of Thunder (Leigong 電公) wedged in a branch and unable to fly away. The branch had been struck by a thunderbolt and then snapped back into place again. ${ }^{79}$ Qianshao found a stone wedge with which he prized the branch open, thus enabling Leigong to get away. The Lord of Thunder thanked him sheepishly and gave him a rendezvous at the same place the following day. When the next day Qianshao arrived beneath the tree at the appointed time, Leigong had also come. He presented him with a scroll in black seal characters, saying: "With this you can cause thunder and rain, cure diseases, and build merit by saving others. We are five brothers. If you want a thunderclap, call Elder Thunder (Leida 雷大) or Thunder Two (Leier 雷二). Thunder Five (Leiwu 雷五) has an impetuous disposition. You should not call him unless it's a matter of critical urgency." From then on, Qianshao used his talisman ( $f u$ 符, i.e. the writing on the scroll) to bring about rain...

This is followed by three episodes bearing out the efficacy of Qianshao's talisman: (1) arrested by the prefect for drunkenness in Jizhou 吉州 (Jiangxi), Qianshao calls the impetuous Leiwu, causing a thunderclap and downpour in the middle of a drought, ${ }^{80}$ and is employed as rainmaker; (2) Qianshao controls flooding of the Yellow River by planting his $f u$ in the embankment at Huazhou 滑州(Honan); (3) performs many healing miracles in the Jiangsu and Zhejiang area. The power of the talisman seems to be independent of the merit of its user (excepting of course his original rescue of Leigong), for Qianshao is "not wont to heed the Taoist precepts." One day, he disappears in the manner of the immortals.

The apologetic nature of the following authentication of the Huangdi yinfu jing 黄帝陰符經 and divulgence of a certified explanation of its abstruse contents is especially remarkable because (1) Du Guangting was himself the author of a

74. Examples of wealth-generating encounters are "Wang Guo 王果" (SGZ 1.1a-b); "Xie Zhen 謝貞" (1.2b-3a); “Hou tianshi 俣天師” (1.6a-b); “Deng Lao 鄧老” (1.13a-b); “Yang Chu 楊初” (1.13b-14a); “Liu Yanguang 劉彦廣” (1.14b-15a); “Scholar Cheng 成生” (4.4b-5b); “Guo Ziyi 郭子儀” (SGZ ap. TG 19.131-32); “Wei Yan 韋畣” (SGZ ap. TG 33.209-210).

75. "Evidential Miracles," 227-33.

76. See Michel Strickmann, "Sōdai no raigi: Shinshō undō to dōka nanshū ni tsuite no ryakusetsu 宋代の雷儀：神霄運動 と道家南宗についての略説.” Tōhō shūkyō 東方宗教 46 (1975): 15-28 and Lowell Skar, "Administering thunder: A thirteenth-century memorial deliberating the Thunder Rites", Cahiers d'Extrême-Asie 9 (1996-1997): 159-202. The following story is found in SGZ 1.3b-4a; ap. Taiping guangji 394.3151 and Yunji qiqian $112.1 \mathrm{~b}-2 \mathrm{~b}$.

77. Taiping guangji emendation: "of the Tang."

78. Taiping guangji variant: "In his youth he gathered firewood and herded animals."

79. The Taiping guangii version reverses the order of the above phrases and substitutes "tree" (i.e., trunk) for "branch:" "The tree was [split] by a thunderbolt and then suddenly came together again. The Lord of Thunder was stuck in the tree and unable to fly off."

80. Echoing a theme in the eighth-century "Liu Yi zhuan 柳毅傳" cited above. 
commentary on this scripture, ${ }^{81}$ and (2) its antiquity was actually in considerable doubt since at least Song and probably Tang times: ${ }^{82}$

Li Quan 李鉒 (fl. between 713-742) lived at Mount Shaoshi 少室山 (in the Songshan 嵩山 range in Henan). An adept of the Way of the Immortals, he regularly roamed the great mountains, searching widely for esoteric methods and skills 方術. When he came to Tiger Mouth Cliff 虎口䉷 at Songshan, ${ }^{83}$ he found a copy of the Secret Talisman of the Yellow Emperor (Huangdi yinfu 黃帝陰符) there. The white silk scroll with vermilion script on a black-lacquered roller was enclosed in a jade casket inscribed with the words: "Secreted in the great mountains by the Supreme Purity Taoist master Kou Qianzhi 寇謙之 (365-448), ${ }^{84}$ on the seventh day of the seventh month of the second year Zhenjun under the Great Wei (441), for transmission to fellow devotees." The copy was in a state of decay. After Quan had copied it out and recited it several thousands of times he still did not understand its meaning.

Upon entering Qin 秦 (Shaanxi) and arriving at the foot of Mount $\mathrm{Li}$ 驪山 (in Lintong county), he encountered an old woman 老母. She wore a topknot, with half her hair hanging loose. ${ }^{85} \mathrm{Clad}$ in tattered clothes and leaning on a staff, she had the air of an extraordinary being. Li Quan perceived a tree in flames by the roadside. The old woman mumbled to herself: "Wood begets Fire; when calamity arises, it must needs prevail 火生於木, 螎發必剋." Quan was startled and asked: “These words are from the Secret Talisman of the Yellow Emperor, Part One.$^{86}$ How did the old lady come by it?" The old woman said: "I already received the talisman six cycles of the three monads' sexagesimal periods 三元六周甲子 ago. And where did the young man get it?" Quan prostrated himself and after repeated reverences fully related how he had obtained it. The old lady said: "The young man's cheekbones connect with the parietal bones, his wheel of fate joins a prominent forehead. Your vitality is undiminished, you have a detached disposition, a virtuous nature, and you are interested in esoteric methods; your spirit is brave and you love wisdom: Indeed, you shall be my disciple!" ... Then, sitting on a rock, she proceeded to explain the meaning of the Secret Talisman to Quan:

"This talisman comprises three hundred characters in all. One hundred expound the Way, one hundred expound Methods, and one hundred expound Stratagems. ${ }^{87}$ Section one contains the Way of the immortals and of embracing the One; the middle section, methods for making the nation prosper and bringing peace to the people; and the final section, stratagems for strengthening one's arms and winning victory in battle. They each foster discernment within and correspond to human concerns without. When it comes to contemplating deeply perceived truth, the Yellow Court and Eight Effulgences 黄庭八景 88 do not measure up to it in subtlety; as for enquiring into matters of

81. The Yinfu jing zhu 陰符經注, which does not survive. See Verellen, Du Guangting, 219.

82. See Xiao Dengfu 蕭登福, Huangdi yinfu jing jinzhu jinyi 黄帝陰符經今詩.今譯, 1. Taipei: Wenjin chuban she, 1996. The following synopsis is from SGZ 1.11a-13a; ap. Taiping guangii 14.1012; Yunji qiqian 112.5b-7b.

83. See Li Xiaoshi, Zhongguo daojiao dongtian fudi lansheng, 83.

84. See Richard B. Mather, "K'ou Ch'ien-chih and the Taoist theocracy at the Northern Wei court, 425-451," in Facets of Taoism, edited by H. Welch and A. Seidel, 103-22. New Haven: Yale University Press, 1979.

85. Suggesting a medium or shaman?

86. See Huangdi yinfu jing 黄帝陰符經 1a. D 27, no. 31. Cf. Xiao Dengfu, Huangdi yinfu jing jinzhu jinyi, 119-20.

87. These indications correspond closely to the current edition in D 27, no. 31 . On the military aspects of the scripture, see Christopher $\mathrm{C}$. Rand, "Li Ch'üan and Chinese military thought." Harvard Journal of Asiatic Studies 39 (1979): 107-37.

88. Essential teachings of Shangqing mysticism. Taiping guangji emends the expression as “Huangting neijing 內景," referring to the Inner Effulgences, the Shangqing version of the Book of the Yellow Court. 
quintessential importance, Scripture, Tradition, Philosophy, and History ${ }^{89}$ are unequal to it as literature; and in exercising skilful perspicacity, Sun 孫, Wu 吳, Han 韓, and Bo 白 ${ }^{90}$ are inferior to its ingenuity. Only gentlemen possessing the Way may be apprised of it. Thus if a perfect man 至人 ${ }^{91}$ uses it, he obtains its Way; if a superior man uses it, he obtains its methods; and if the common people use it, they meet with disaster. Each has a different degree of understanding. To transmit it to fellow devotees, one must celebrate a pure retreat 清齋 (i.e., observe the ordination rites) before bestowing it."

A long time had passed. The old woman produced some wheat meal and drew a gourd from her sleeve with which she sent Quan to fetch water from the valley. Once it was filled with water, the gourd suddenly grew so heavy that Quan did not have the strength to hold it and it sank into the source. When he returned, the old woman had already disappeared. All that remained was the wheat meal. Quan ate it and from then onwards abstained from eating cereals. ${ }^{92}$

\section{Lay society and Taoist clergy}

The humble guise assumed by immortals in this world raises, like the Christian image of the messiah as man and sacrificial victim, a mystical paradox that also challenges preconceived ideas about worldly and spiritual hierarchies in actual society. In the Shenxian ganyu zhuan visiting immortals pose as shoulder pole bearers carrying heavy burdens, market vendors, and menial laborers. ${ }^{93}$ The role they assume in human society is exemplified by tales about immortal servants. In the first example, the classic theme of the "banished immortal 謫仙" appears as a variant of this motif:

In 806-820, the xiucai 秀才 graduate (of the first degree in the imperial examinations) Quan Tongxiu 權同休, while roaming amongst the lakes and seas, meets with poverty and disease. Having hired a villager as servant 傦雇, he orders him to buy licorice root 甘草 in the market and prepare "sweet bean soup 甘豆湯. When in the end the servant fails to carry out these errands, Tongxiu reprimands him for his idleness; the servant then breaks twigs and makes licorice root by rubbing them together. Next, the bean soup is prepared from coarse sand. The graduate's health is restored after eating these, and he again sends the servant to the market to make provisions for a village feast. This time, the servant magically produces quantities of beef and wine. Thereupon Tongxiu contritely apologizes for his previous disregard of the "Taoist" and offers to reverse roles by serving him as the master. The Taoist refuses, explaining that he had been banished 謫 to the world of

89. I.e., the four fundamental categories of writings.

90. I.e., the famous strategists Sun Wu 孫武 (6th c. BC) and Wu Qi 吳起 (440-381) and generals Han Xin 韓信 (d. 196 BC) and Bo Qi 白起 (d. 257 BC) of the Warring States and Former Han periods.

91. Cf. Zhuangzi 莊子, “Qiwu lun.” Guo Qingfan 郭慶藩 ed., Zhuangzi jishi 壯子集釋 2.96. Peking: Zhonghua shuju, 1961.

92. A mark of the immortals; see Jean Lévi, "L'abstinence des céréales chez les taoïstes," Études Chinoises 1 (1983): 3-47. Here wheat meal is offered, paradoxically, as the cereal to end all cereals.

93. Porters: “Yu Manchuan 于满川" (1.5b-6a), "Hou tianshi 俣天師” (1.6a-b), “Liu Yanguang 劉彦廣” (1.14b-15a), “Ziluo Ren sou 紫邏任舅” (5.15a-b); vendors: "Liu Yanguang” (see above), “Hermit Lu 盧山人” (2.10b-12a); laborer: "Xie Zhen 謝貞” (1.2b-3a); monastic servant: "Monk of Oxhead Monastery, Zizhou 梓州牛頭寺僧” (4.11b-12b). A related type of story features the same social categories as recipients of immortals' favors: e.g., “Mou Yubin 车羽貿” (1.4b-5b) and "Oil vendor Dongming 東明油客” (4.10a-b). 
mortals, in the role of Tongxiu's domestic servant 僕役, as punishment for a transgression. ${ }^{94}$

Retainer Li Gongzuo 李公佐 has a coachman 樸夫, described as "a working man of the people, unvaryingly diligent and respectful." After having served unrecognized in this capacity for thirty years, he suddenly departs, leaving behind a poem that identifies him as Su Dan 蘇耽, an immortal of antiquity..$^{95}$

Huan Kai 桓闇 was the servant of Tao Hongjing 陶弘景 (456-536), a lowly eccentric who was in the end favored by the gods above his learned master: ${ }^{96}$

He served Master Tao as his acolyte-of-all-work 執役之士, and wore himself out in toil for more than ten years... Beyond his menial duties he engaged in no spiritual practices. One morning, two youths came down from heaven on a white crane, right into master Tao's court yard. Tao was enraptured and went out onto the veranda to receive them. But the youths said: "The Most High has commanded us only to ask for master Huan." Master Tao said nothing, only thinking inwardly that there was no one named Huan among his disciples. Yet he gave orders that the person be sought for, and it turned out to be none other than Huan the menial...

The following story confronts the question of social barriers head-on, addressing several contentious issues at the same time: the decline of the aristocracy and rise of the merchant class under the Tang; the complacency of superficial "devotees of the Way," and the risk of spiritual failure inherent in worldly privilege: ${ }^{97}$

Zheng Youxuan 鄭又玄 was the scion of a great family residing in Chang' an. ${ }^{98}$ When he was young, he was studying under a tutor together with the son of the neighboring Lüqiu 呂丘 family. Youxuan had a conceited nature. Because of his family's prestige and nobility and the humble station of the Lüqiu family, he constantly taunted [his fellow pupil], saying: "Although mere riffraff 非類, you study together with me! Even without my saying so, how could you not feel inwardly ashamed?" The Lüqiu boy suffered these humiliations in silence. A little over a year later ${ }^{99}$ he died.

Ten years later again, Youxuan passed the classics examination 明經 with distinction and was appointed to the post of administrator 參軍 of Shuzhou 蜀州 (Sichuan). ${ }^{100}$ When he arrived at his office, the commandery prefect posted him to Tangxing 唐興. There he shared lodgings with a scholar named Qiu 仇生, the son of a rich merchant 大賈. He was just at the age of the capping ceremony (i.e., about twenty years). His family's fortune was reckoned in the tens of thousands. Every day he treated Youxuan to various entertainments, and Youxuan repeatedly received gifts of money from him. But because scholar Qiu did not belong to the literati class 士族, Youxuan never treated him with

94. Synopsis, SGZ 2.12a-13a.

95. Synopsis, SGZ 3.7b-8a. On Su Dan, see Dongxian zhuan ap. Yunji qiqian 110.12a-b.

96. SGZ ap Taiping guangji 15.106. The synopsis below is taken from Michel Strickmann, "Saintly fools and Chinese masters (Holy Fools)." Asia Major 3d ser. 7. 1 (1994): 38. For the story of Huan kai, see especially Huan zhenren shengxian ji 桓真人升仙記 (ca. 10th c.). D 151, no 301.

97. SGZ 4.2a-4a; ap. Yunji qiqian $112.21 \mathrm{a}-22 \mathrm{~b}$. A closely related and near-contemporary version of this story is found in Xuanshi zhi 宣室志, by Zhang Du 張讀 (fl. betw. 881-884), ap. Taiping guangji 52.322-23.

98. Xuanshi zhi specifies that he was a Zheng of Yingyang 榮陽. On this clan, celebrated in ninth-century Chang'an society and literature, see Glen Dudbridge, The tale of Li Wa: Study and critical edition of a Chinese story from the ninth century, 39-52. London: Ithaca Press, 1983.

99. Xuanshi zhi variant: "a few years later."

100. Xuanshi zhi variant: "of Tang'an commandery 唐安郡." 
courtesy. One day, Youxuan gave a reception which scholar Qiu was unable to attend. Halfway through the party someone ${ }^{101}$ said to Youxuan: "Scholar Qiu shares lodgings with you. Is Scholar Qiu not amiss ${ }^{102}$ in not attending a banquet given by you?" Youxuan felt shamed and summoned Qiu. When he arrived, Youxuan proffered a cup for him to drink. The scholar excused himself from draining the cup. When he persisted in refusing [the wine], Youxuan abused him angrily: “You market-place commoners 市井之甿 know nothing but petty profit. How can you presume to lodge with a ranking official? That for the moment I should associate with you is your good fortune - how dare you refuse this wine?" With this, he shook [the dust from] his garment ${ }^{103}$ and rose. Scholar Qiu withdrew, deeply humiliated. He renounced his official career and shut himself in. A month later he fell ill and died. ${ }^{104}$

The following year, Youxuan resigned his office and went to live in Mengyang 濛陽 (in Pengzhou, Sichuan). ${ }^{105}$ Youxuan, who had long been a devotee of the Way of HuangLao 黃老, had heard of a Taoist master Wu 吳 in the mountains of Shu ${ }^{106}$ whom he held in high esteem. He went to call on him, wishing to becoming his disciple. After he had been kept for as long as ten ${ }^{107}$ years without receiving any bestowal (i.e., ordination or esoteric transmission), Youxuan indolently took his leave and returned.

Later, on his return journey to Chang'an, he stopped overnight in Baocheng 㠇城 (Mianxian, Shaanxi). At the inn, there was a youth some ten years of age, with a distinguished and intelligent look. When Youxuan engaged him in conversation, he proved so eloquent and subtle that Youxuan was profoundly amazed. The youth said to Youxuan: "You and I are old acquaintances of many years standing, do you realize?" Youxuan replied: "I do not remember." The youth said: "I was born into the Lüqiu family and lived in Chang'an. We studied together, but you constantly abused me as 'riffraff.' Then I was the son of the Qiu family. You were posted to Tangxing and we shared lodgings together. You accepted my largesse but called me a 'market-place commoner.' How very arrogant you are! To scorn other beings because you belong to a family of courtiers 衣縜 is indeed contrary to the Way! I am a Perfected of the Taiqing 太清 [Heaven]. Because the Emperor on High 上帝 considered that you possessed the spirit of the Way 道氣, he ordered me to be born into the world of mortals in order to befriend you and transmit the secret instructions of the immortals to you. Yet with your recklessness and haughtiness you were never able to obtain their Way. Truly, you are to be pitied!" With this, the youth suddenly vanished.

Youxuan then awoke to his sinfulness, and he died of remorse.

Having cast this uncompromising light on social prejudice in his time, and on the obstacle it placed in the path of an individual's spiritual advancement, Du Guangting examines another vexing question for the Taoist community in relation to Chinese society: the Buddhist ideal of "leaving the family 出家” to take religious orders was widely accepted by this time, despite its incongruity with the Chinese ideal of "filial devotion 孝." To the Taoist, holy orders, associated with the status and functions of officialdom, were moreover in conflict with the cherished ideals of personal liberation, independence of thought, and self-sufficiency. Where the tale of Zheng Youxuan

101. Yunji qiqian variant: "a friend."

102. Xuanshi zhi variant: "How could Scholar Qiu not be at fault..."

103. zhenyi 振衣: an expression of contempt.

104. Xuanshi zhi variant: "He discontinued all human commerce. A few months later, he fell ill and died."

105. Xuanshi zhi variant: "and went to live in a Buddhist monastery in Mengyang commandery."

106. Xuanshi zhi variant: "in the Shumen mountains 蜀門山."

107. Xuanshi zhi variant: "fifteen." This text features two dialogues between master Wu and Youxuan omitted in the present version. 
reflects the social tensions of Tang "secular" society and their religious implications, the following story speaks specifically to the Taoist clergy and laity: ${ }^{108}$

In the Fuye temple 福業觀 at Caoqiao 曹橋 in Hangzhou (Zhejiang) there lived a reverend master Pan 潘尊師 whose household was well-to-do. Pan was modest, magnanimous, hospitable to strangers, and aided others by means of meritorious works.

One day a youth of extraordinary appearance paid a visit to the temple ${ }^{109}$ and announced to Pan: "I have heard from afar that the Master's virtue relieves those in distress. I beg permission to put up in the thatched guest lodging on the bamboo path behind the Master's oratory for two months in order to escape from dire peril. Would you consent to this? If you grant your kind permission, I shall neither cause you bother nor trouble you for provisions. All I request is two measures 斗 of wine which should sustain me for sixty days." Although Pan had no inkling whence [the visitor] had come, when he heard that he sought to escape from adversity, he happily consented. The youth then lodged in the thatched hut. No one sought him out, and neither did he eat or drink. At the end of the sixty day period, he again paid his respects to the master and took his leave. Casually, he asked Pan: "Have you in the past received any ordinations?" Pan said: "I have already received those up to the middle oath 中盟 of the Dongxuan 洞玄 [canon], ${ }^{110}$ but have not yet presumed to seek advancement to the higher rites." The youth said: "The master's ordination rank is already high. However, I shall raise it to the One and Orthodox Register of the Magistrate of the Nine Provinces Soil God 正一九州社令籙, First Degree. Every offence will be related to you, all reports answered."

Thereupon he burnt incense before the Celestial Worthy 天尊 and transmitted to Pan the name and given name of the magistrate of the soil god as well as those of the spirit officers, military and civil. Then he issued a summons for foot soldiers and horsemen who all promptly arrived on the scene. Next, he commanded them: "After this ordination, you shall form the reverend master's guard troops. His summonses and orders will be as those of the magistrate." Thereupon the troops disappeared. Again he spoke to Pan: "You should build a bench, make an altar, and set up a scripture table in the central hall. When you burn incense and sit in reverence, every event, happy or unhappy, within and without the Nine Provinces [i.e., China], shall be known to you. Only do not profane [your tutelary powers] with pungent or bloody foods, nor be negligent or disobedient. You should certainly be held to account for it in the underworld! With purity and mindfulness, however, you may accede to long life and immortality." Having said this, he disappeared from sight, it is not known whereto.

Pan then set up a couch and, leaning on a low table, sat in the central hall. Within a short while he became aware of every single event in the world, regardless of its importance. When this had gone on for ten days, the reports of the spirit officials amounted to such a hubbub that Pan suddenly declared: "I am a man of leisure. Why must I know the affairs of all the world?" And he strictly curtailed the spirit officers' transmission of the reports. They replied: "It will not do for the official in charge to be remiss. If the reports are numerous, restrictions won't stop them." Pan then ate meat and swallowed garlic in order to put an end to it. In three or five days the sound of the reporting gradually receded. Then the spirit officers stopped appearing, and it was over. 111

One night, the youth came to him and said: "I have lightly transmitted the secret instructions of the Perfected to you and have incurred a reprimand. The master's crime of desecrating the Perfected spirits must be examined in the underworld. But mindful of the

108. SGZ 3.4a-6a; ap. Yunji qiqian $112.15 \mathrm{~b}-17 \mathrm{~b}$.

109. Cf. the story of "Fei Xuanzhen 費玄真," SGZ $2.6 \mathrm{~b}-7 \mathrm{~b}$, about a saintly visitor and supernatural draftsman to the Xing Tang guan 興唐觀 temple in Chengdu.

110. On ordination "oath documents 盟文" from the mid-Tang period preserved at Dunhuang, see Schipper, "Taoist ordination," 135; on the canon classification in relation to the ordination system, ibid., 128-29.

111. Cf. the story of "Du Hui 杜䀲," SGZ 5.2b-3a, who first obtains healing and longevity, but in the end returns to aging after breaking his vows. 
kindness received through your liberality towards me when I came before, I cannot watch your fall with indifference. I shall separately bestow on you a technique for greatly accumulating hidden merit. By saving others from the sufferings of disease you will redeem your former fault. Otherwise you shall fall into the prisons of hell." Pan had realized this himself as soon as he had placed the impure food into his mouth. Hearing these words now put him into a state of extraordinary anxiety.

The youth then took some rice powder 米屑, mixed it [into a paste], and made a human figure four or five inches tall. This he placed into a cavity in the wall. He further bestowed on him two Yuzi 玉子 talismans, ${ }^{12}$ admonishing Pan as follows: "When those suffering from disease and distress among the people come seeking relief, you should enquire the cause of their affliction from the [rice] flour figure. Then you may deliver them by means of my talismans. You shall not obtain strings of cash but apply yourself to the accumulation of merit for the redemption of your transgression only. Be diligent without fail. After ten years I shall return."

From then onward, Pan came to the relief of men with vermilion seal script, expelling afflictions and curing diseases. Those to whom he attended were like [the crowds in] the market place. Somewhat over ten years later, the youth ${ }^{113}$ returned. He sojourned for more than a month, discoursing at length about matters concerning the various heavens and life in religion. Then he took his leave and departed. About a year later, Pan died without having been ill. I believe he had attained the Way of corpse-liberation 户解. ${ }^{114}$

Thus Pan becomes an immortal despite himself. Through the grace of an encounter, he is given the opportunity to attain salvation by performing religious duties. But after a short trial period, he finds this vocation not to his taste ("I am a man of leisure. Why must I know the affairs of all the world?"). The author Du Guangting, himself the leading Taoist prelate of his time, seems to agree with the reverend master Pan in regarding the privileges and duties attached to his raised ordination rank as a superfluous and noxious bother, in terms that echo the Taoist philosopher Zhuangzi's famous refusal to serve at court. ${ }^{115}$ In another work, Du denounces a sanctimonious Taoist clergyman, literally dispatching him to hell. ${ }^{116}$ If vocation is not a specially recommended path to salvation, neither are regard for the precepts (Ye Qianshao was "not wont to heed the Taoist precepts"), comprehension of doctrine (Wang Kejiao was "a peasant by origin and had no initial knowledge of the Way"), regular practice ("Beyond his menial duties, Huan Kai engaged in no spiritual practices") or skills (Chen Jian "had never been able to read seal characters") absolute prerequisites for attaining the highest goals of Taoism. On the other hand, the commonest way to become an immortal, in the pages of the Shenxian ganyu zhuan, is through karmic retribution for accumulated merit, not originally a Taoist concept at all: The opening enigma of the

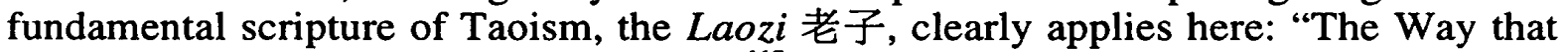
can be postulated, is not the eternal Way."117

112. Named for the immortal Yuzi? (Wei Zhen 韋震); see Shenxian zhuan ap. Taiping guangji 5.24-25.

113. Yunji qiqian variant shaonian 少年 for nianshao.

114. Cf. Anna Seidel, "Post-mortem immortality or the Taoist resurrection of the body." In Gilgul: Essays on transformation, revolution and permanence in the history of religions, 223-37. Leiden: E.J. Brill, 1987.

115. See the parables of the sacred tortoise and the sacrificial ox in Zhuangzi, "Qiushui" and "Lie Yukou," respectively (Guo Qingfan ed., Zhuangzi jishi 17.603-4 and 32.1062).

116. "Zhang Renbiao 張仁表," a Taoist cleric of Chang'an. See Daojiao lingyan ji 5.1 a-3a and Verellen, "Evidential Miracles," 240-43.

117. Zhu Qianzhi 朱謙之 ed., Laozi jiaoshi 老子校釋 1.3. Peking: Zhonghua shuju, 1980. 


\section{Résumé}

La rencontre comme révélation : Un motif hagiographique taö̈ste dans la Chine médiévale

Le recueil taö̈ste Rencontres avec les immortels, le Shenxian ganyu zhuan de Du Guangting (début du $\mathrm{X}^{\mathrm{c}}$ siècle), regroupe une centaine de récits hagiographiques autour du thème de la "rencontre" révélatrice. La manifestation du divin aux hommes a servi depuis l'antiquité chinoise comme métaphore de la communion mystique. Le présent article retrace le développement de cette notion à travers l'hagiographie taö̈ste ancienne et médiévale, puis examine la pensée et la pratique taoïstes relatives à la quête délibérée de la rencontre exemplifiées dans le Shenxian ganyu zhuan. L'accent est mis sur certains éléments-clés qui caractérisent les contacts et les transactions entre hommes et immortels auxquels donnent lieu les rencontres : le passage de la frontière entre ce monde et l'audelà, seuil franchi, souvent à l'occasion d'un "événement-déclencheur"; le but et la nature de la faveur espérée (recettes et objets conférant immortalité ou longévité écritures, talismans, drogues, nourriture) ; l'importance primordiale des textes, et de la capacité de lire et d'écrire, pour l'œuvre du salut. Enfin, le Shenxian ganyu zhuan s'avère une source précieuse pour appréhender la vie sociale à la fin des Tang. Grâce au choix des immortels venus au monde pour mettre les hommes à l'épreuve, nous y rencontrons un éventail de métiers courants - souvent en rapport avec les marchés urbains et ruraux en plein développement à cette époque (coolies, vendeurs, artisans divers), et entrevoyons la composition d'un nouveau patronage religieux (marchands, militaires, administrateurs locaux) à la veille de la Chine moderne. 